\title{
"Johns" in the Spotlight: Anti-prostitution Efforts and the Surveillance of Clients
}

Ummni Khan*

\begin{abstract}
This essay examines surveillant practices that subject sex trade clients ("clients") to socio-legal control. In particular, I employ the concepts of the gaze, voyeurism, and exhibitionism to unpack the surveillant dynamics, and consider how power and pleasure are harnessed, produced, and thwarted in the increasing scrutiny of the sex trade's demand side. I further examine my own research of the regulation of clients within this analytical framework. Following David Lyon's insights on the scopophilic dimensions of surveillance (2006), I argue that the instrumental goals of surveillance are interconnected with a voyeurism that gratifies the pleasures of looking at, categorizing, defining and making sense of, clients. Yet, bearing in mind the multi-directionality of the gaze, I also analyze the controlled exhibition of sex work signifiers, as information is not just gathered, but also displayed and performed.
\end{abstract}

Keywords: sex work, prostitution, clients or “johns," surveillance, panoptic, synoptic, social control, voyeurism, exhibitionism, the gaze, criminal law and regulation, media studies

\section{Résumé}

Cet article examine les pratiques de surveillance qui assujettissent les clients de l'industrie du sexe (les "clients ») à un contrôle sociojuridique. En particulier, jemplois les concepts du regard, du voyeurisme et de l'exhibitionnisme afin de révéler les dynamiques de surveillance, et d'examiner comment le pouvoir et le plaisir sont canalisés, produits et entravés par l'examen de plus en plus minutieux de la demande dans le commerce du sexe. Dans ce cadre analytique, j'approfondie ma propre recherche sur la réglementation des clients. En mappuyant sur les idées de David Lyon portant sur les dimensions scopophiliques de la surveillance (2006), je soutiens que les objectifs fondamentaux de la surveillance sont liés au voyeurisme, donnant ainsi plaisir à regarder, classer, définir et donner un sens aux clients. Toutefois, compte tenu du caractère multidirectionnel du regard, j'analyse également l'exhibition contrôlée des signifiants propres au travail du sexe, puisque l'information n'est pas seulement recueillie mais aussi exposée et représentée.

\footnotetext{
* I thank my Research Assistant Amanda Boyce for her outstanding work. I am grateful for the insightful feedback I received from Brian Smith, Lara Karaian, Shoshana Magnet, Rachel Debrofsky, participants of the Critical Criminology Conference at Carleton University 2014, the two anonymous reviewers and Mariana Valverde. Finally I thank SSHRC for research support that made this article possible.
}

The online version of this article is published within an Open Access environment subject to the conditions of the Creative Commons Attribution licence http://creativecommons.org/licenses/by/3.0/ Canadian Journal of Law and Society / Revue Canadienne Droit et Société, 2015, 
Mots clés : Industrie du sexe, prostitution, clients, surveillance, panoptique, synoptique, contrôle social, voyeurisme, exhibitionnisme, le regard, droit pénal et réglementation, études sur les médias

\section{Reflection from the Field: Checking the Johns Out}

Clutching the flimsy garments in my hand, I wonder what would be less provocative: a low-cut top that gives a glimpse of cleavage or a clingy sheer blouse that reveals the outlines of my bra. Two very inappropriate outfits, but all I had packed for this weekend's field research. I opt for the V-neck.

An hour later, I'm sipping a soy latte and wandering the hallways of a mostly vacant government building. As I make yet another wrong turn, I encounter a young man who seems to know what's what in there. He has crinkly unkempt hair, a Styrofoam cup in one hand, and a cane in the other. Cute guy. Cute grin. Suddenly, I'm glad my shirt's revealing. He asks me if I need directions, and I nod, telling him the room number. Apparently, he has already staked out the place. As we walk, he jokes about the mazelike corridors so I don't feel bad about being lost. I smile in agreement, but when I realize why he's there, I have to stop myself from getting chatty. I did not receive research ethics approval to talk with him. I'm only allowed to observe. He's been designated a "john"- that is, someone who pays for sex-and he has been sent to rehab to learn the error of his libido. I'm here to study the court diversion program designed for him and other men who were caught attempting to buy sex from undercover police officers.

The john school I am observing that day is run by current and retired male police officers. When I introduce myself, I am greeted warmly. They consider me one of them. I guess they figure as a professor, but perhaps more important, as a woman, I will undoubtedly agree with them that prostitution is wrong and that these men should be disciplined and reformed.

The room is set up like a small lecture room, the kind in which I might teach an undergraduate class. At the front are a table, chair, and projection screen that face three rows reserved for the court-mandated audience. Behind them is another row for the presenters, those with professional knowledge or personal experience who will attest to the harms of prostitution and try to get these men to rein in their wayward desires. I am assigned a seat in the back row, where I can surreptitiously take notes. I open up a blank book and write at the top: "What ideological constructions of sex work does john school perpetuate?" That's my research question. The day's presenters provide plenty of data. A police officer equates all prostitution with sex trafficking; a sexual health nurse shows menacing slides with close ups of herpes and genital warts; a recovering sex addict invites the men to view their behaviour as a mental health problem; a community representative admonishes the men for bringing prostitution into 'decent' neighbourhoods; a client's wife bemoans the destruction of her marriage because of her husband's infidelity; and a former prostitute narrates how drugs, abuse, and povertynot choice-drove her into the trade. I scribble detailed notes throughout the day, but in a parallel part of my brain, I'm checking the guys out.

All of these men were busted in sting operations on the street, so none had the money or the inclination to hire an escort. Too bad for them. Clients of 
escorts are seldom caught by what the newspapers often refer to as "john sweeps." As I study each man's back, I find myself wondering what kind of sex he was after and why. Having read a number of empirical studies on the topic, I gather that some are single and horny, others are not getting the desired kind of sex or enough sex from their girlfriends or wives, some like to have sex with a variety of women, others want women who possess specific physical characteristics, some get off on the risk, others seek emotional intimacy, and some, because of their low currency on the courtship market, just cannot get laid any other way.

During the lunch break, the cute guy from the morning intercepts me on the way out and asks, "You're here to investigate us perverts?" There is a tension between us now that had not existed before. It makes sense. We're on opposite sides of the criminal status divide; he's in trouble with the law, and I'm a legal studies professor. I assure him that I'm just studying the program itself, not the men in attendance, but he's not convinced, sensing that I'm keeping something from him. He's right, of course, but it's not what he thinks. It's my own prurient thoughts that I'm hiding: surveying him along with his peers and wondering not just what their kinks might be, but also whether any would pay to have sex with me.

\section{Introduction}

My observation of john school illustrates the complex dynamics of the academic gaze. I share this recollection not only to highlight that there is no neutral vantage point from which to conduct research, but also to expose academic complicity in the surveillance of sexual others. In sex work research, this self-reflexivity is politically and epistemologically important. As Leslie Jeffrey and Gayle MacDonald argue, researchers should be cognizant of both their privileged position as knowledge producers and of their own investments. ${ }^{1}$ Jill Nagle has further charged that when people who are not sex workers write about prostitution, often "[their] own personal fascinations (or repulsions) go unmentioned or grossly undertheorized." I take this criticism seriously, particularly because my topic draws on surveillance, which, as Kevin Haggerty explains, "involves monitoring people or things typically as the basis for some form of social intervention." 3 While my overt research agenda was to glean the program's ideology, the clients were inevitably implicated in my peripheral observation. As such, the first section of this paper describes my methodology in studying john schools and interrogates the above anecdote.

The crisscrossing trajectory of looks at play in that anecdote introduces some of the power and pleasure regimes that I address in this essay. As Foucault reminds us, power is not simply repressive, top-down, or unidirectional. ${ }^{4}$ Rather, a network

1 Leslie Ann Jeffrey and Gayle MacDonald, Sex Workers in the Maritimes Talk Back (UBC Press, 2011).

$2 \quad$ Jill Nagle, "Reviewed Work (s): Making Work, Making Trouble: Prostitution as a Social Problem by Deborah R. Brock; Prostitution, Power, and Freedom by Julia O'Connell Davidson; Sex Work and Sex Workers by Barry M. Dank; Roberto Refinetti Sex for Sale: Prostitution, Pornography, and the Sex Industry by Ronald Weitzer," Signs 27, no. 4 (2002): 1177-1183, at 1182.

3 Kevin Haggerty, "Surveillance and Political Problems," in Surveillance: Power, Problems, and Politics, ed. Sean Patrick Hier and Joshua Greenberg (UBC Press, 2009), ix.

4 Michel Foucault, Power/Knowledge: Selected Interviews and Other Writings, 1972-1977 (Random House Digital, 1980). 
of forces emanates from multiple sources and pushes in multiple directions, from the official word of the law to the micropractices of everyday engagement. Furthermore, laws against sex work do not repress pleasure or instinct; instead, the prohibitions incite new articulations of sexuality. ${ }^{5}$ Kevin Walby and André Smith have advocated for cross-fertilization between surveillance studies and the sociology of sexual regulation, particularly because "understandings of sex and sexuality as deviant and risky are in part produced by surveillance." ${ }^{6}$ Using this hybrid framework, I seek to deconstruct how power and pleasure are harnessed, produced, and thwarted in the increasing scrutiny of the sex trade's demand side.

At its most basic level, surveillance speaks to the ways clients are monitored in order to regulate, discipline, and criminalize them. Alongside this function of constructing criminality, scholars have also concluded that much surveillance has a scopophilic or voyeuristic dimension. ${ }^{7}$ While scopophilia (pleasure in looking) and voyeurism (observation of erotic or private activity) are Freudian concepts, they have been appropriated by critical, film, and feminist theories. In particular, Laura Mulvey argued in 1975 that within cinematic voyeurism, the camera angle encourages a gendered binary that codes the "gaze" as active and male, while the passive female is signified by her "to-be-looked-at-ness." Rachel Dubrofsky have shown how this notion of a controlling gaze can enrich surveillance studies' insights about the burgeoning ways disenfranchised bodies are placed under objectifying scrutiny. ${ }^{9}$ My analysis builds on these insights, but as my anecdote demonstrates, the male-female binary is destabilized. A female academic, just like police officers or community members of any sex, can subject male clients to a voyeuristic gaze that treats them as objects of desire, curiosity, and deviant spectacle.

While voyeurism has received some attention from surveillance scholars, exhibitionism has been less theorized within this context. ${ }^{10}$ In psychoanalytic theory, exhibitionism is the flip side of voyeurism in that, instead of surreptitious looking, the desire is to compel others to look, to subject an audience, consensually or nonconsensually, to a sexual display. In my research, I found that surveillant practices of clients often give rise to a "social intervention" that manifests as a form of exhibitionism, where sex work signifiers are reproduced within a moralizing discourse. Those who criminalize and discipline clients do not just gather information, but also package and perform this constructed knowledge to accomplish ideological, political, and latently perverse goals.

5 Michel Foucault, The History of Sexuality: The Use of Pleasure, vol. 2, (Random House Digital, 1990).

6 Kevin Walby and André Smith, "Sex and Sexuality under Surveillance: Lenses and Binary Frames," in Policing Sex, ed. Paul Johnston and Derek Dalton (Routledge, 2012), 54-63.

$7 \quad$ Ibid., 54; Kevin Walby, "Police Surveillance of Male-with-Male Public Sex in Ontario, 1983-94," in Surveillance: Power, Problems, and Politics, 46; and David Lyon, "9/11, Synopticon, and Scopophilia: Watching and Being Watched," in The New Politics of Surveillance and Visibility > 2006), 35-54.

$8 \quad$ Laura Mulvey, "Visual Pleasure and Narrative Cinema," in Feminisms: An Anthology of Literary Theory and Criticism (New Brunswick, N.J: Rutgers University Press, 1975), 438-48.

9 Rachel Dubrofsky and Shoshana Magnet, Feminist Surveillance Studies (Duke University Press, forthcoming).

10 One notable exception is David Bell's article, "Surveillance is Sexy," in Surveillance \& Society 6, no. 3 (2009): 203-12 that I will draw upon in the analysis of my anecdote. 
In my analysis of this complex surveillance of sexuality, I first unpack my anecdote as an instance of the academic gaze implicated in a voyeuristic-exhibitionist dynamic and then turn to five social control practices that occur in Canada: undercover sting operations; "Dear John" letters sent to men whom police suspect are cruising for sex work; "Report-A-John" police websites that draw on the public to gather information on potential clients; police-generated media reports that publish the names of men arrested for prostitution-related offences; and john school diversion programs that set out to educate clients about the "harms" of prostitution, with a focus on the "sex addiction" component of the program. I focus on the regulation of street level sex work because although it only accounts for less than 20 percent of the trade in Canada, ${ }^{11}$ the street attracts the most intense police efforts. ${ }^{12}$

It should be noted that the legal authority that has supported these social control strategies has recently been altered. Before December 2013, it was virtually impossible to engage in sex work without committing a crime. ${ }^{13}$ Outdoor sex work was caught by provisions prohibiting solicitation in public places (Criminal Code s. 213 (1) (c)), and indoor sex work was caught by provisions prohibiting the operation of bawdy-houses (Criminal Code s. 210). This two-faced legal order left the act of exchanging money for sex lawful but rendered the means to practice the trade criminal. In December 2013, the Supreme Court of Canada found these laws unconstitutional, primarily on the basis that they violated sex workers' health, safety, and security. ${ }^{14}$ The Canadian government has responded by passing Bill C36, the Protection of Communities and Exploited Persons Act in December of 2014. The new laws make it criminal for a person to buy sex and also continue to criminalize any party involved with the sale of sex in public places where children might "reasonably" be expected to be present-a prohibition that would presumably include anywhere on the street. Thus, it seems that the new model, along with ignoring the security issues addressed in $R v$ Bedford, goes one step further in stigmatizing clients by directly criminalizing them in all circumstances and exceptionalizing street sex work as a particular danger zone where selling continues to be criminalized for both parties. This public display of the sex trade is thus singled out for its unsettling visibility, translated by community residents, police, politicians, feminist prohibitionists, and the media as nuisance, danger, and gendered victimization. ${ }^{15}$

11 House of Commons, Standing Committee on Justice and Human Rights, The Challenge of Change: A Study of Canada's Criminal Prostitution Laws: Report of the Standing Committee on Justice and Human Rights [and] Report of the Subcommittee on Solicitation Laws (House of Commons Canada, 2006), 19; http://www.parl.gc.ca/Content/HOC/Committee/391/SSLR/Reports/RP2610157/391_ JUST_Rpt06_PDF/391_JUST_Rpt06-e.pdf.

12 Jill McCracken, Street Sex Workers' Discourse: Realizing Material Change Through Agential Choice (New York: Routledge, 2013); Melissa Ditmore, Prostitution and Sex Work (ABC-CLIO, 2010).

13 John Lowman, "Violence and the Outlaw Status of (Street) Prostitution in Canada," Violence Against Women 6, no. 9 (2000): 987-1011.

14 Canada (Attorney General) v Bedford [2013] SCC 72.

15 See Deborah Brock, Making Work, Making Trouble: The Social Regulation of Sexual Labour (University of Toronto Press, 2009) and Jill McCracken, Street Sex Workers' Discourse: Realizing Material Change through Agential Choice. For an example of the feminist antiprostitution perspective, see Janine Benedet, "Pornography and Prostitution in Canada: The Dangers Ahead," in Pornography: Driving the Demand in International Sex Trafficking (2007), 306-20. 


\section{Strategies and Effects of the Surveillance of "Johns"}

\section{My Research Project and the Phenomenology of Studying John Schools}

The data in this article is drawn from research I have been conducting for a two-year Social Science and Humanities Research Council project entitled, "Sex Buyer Beware: Constructions and Representation of Sex Trade Clients and their Impact on Law." In the social science and medical literature, there is an expanding body of work that treats the male client as an important object of knowledge. ${ }^{16}$ Much of the scholarly research is based on interviews and empirically driven to get at the truth of the male client demographic, or it looks only peripherally at the construction of the male client in legal and popular discourses. My project intervenes in this literature by focusing on the male client as a construct whose significance has legal and political effects. I aim to interrogate the regulation and representation of male clients in both law and culture and explore how these two fields interact. ${ }^{17}$ For this article, I focused on how street-based male clients were regulated and represented in surveillant policing practices. What I found during my john school observation, however, was that the very research I conducted gave rise to an academic surveillance power-pleasure dynamic with the clients in attendance despite my intentions to focus solely on the speakers who made up the program.

16 See, for example, H. R. Holzman and S. Pines, "Buying Sex: The Phenomenology of Being a John," in Deviant Behavior 4, no. 1 (1982): 89-116; Lewis Diana, The Prostitute and Her Clients: Your Pleasure is Her Business (Springfield, Ill.: Thomas, 1985); Matthew Freund et al., "Sexual Behavior of Clients with Street Prostitutes in Camden, NJ," The Journal of Sex Research 28, no. 4 (November 1991): 579; E. V. Morse, P. M. Simon, P. M. Balson, and H. J. Osofsky, "Sexual Behavior Patterns of Customers of Male Street Prostitutes," Archives of Sexual Behavior 21, no. 4 (1992): 347-57; Jan Jordon, "User Pays: Why Men Buy Sex," Australian and New Zealand Journal of Criminology 30 (1997): 55; Elroy Sullivan and William Simon, "The Client: A Social, Psychological, and Behavioral Look at the Unseen Patron of Prostitution," in Prostitution: On Whores, Hustlers, and Johns, ed. James E. Elias et al. (Amherst, New York: Prometheus Books, 1998) 134.; Elizabeth Bernstein, "The Meaning of the Purchase Desire, Demand and the Commerce of Sex, "Ethnography 2, no. 3 (2001): 389-420; N. B. Busch, H. Bell, N. Hotaling, and M. A. Monto, "Male Customers of Prostituted Women: Exploring Perceptions of Entitlement to Power and Control and Implications for Violent Behavior Toward Women," Violence Against Women 8, no. 9 (2002): 1093; John Lowman and Chris Atchison, "Men Who Buy Sex: A Survey in the Greater Vancouver Regional District," The Canadian Review of Sociology and Anthropology 43, no. 3 (2006): 281; Martin A. Monto, "Prostitutes' Customers: Motives and Misconceptions," in Sex for Sale: Prostitution, Pornography, and the Sex Industry, ed. Ronald John Weitzer, 2nd ed. (New York: Routledge, 2010); Chris Atchison, "Report on the Preliminary Findings for John's Voice: A Study of Adult Canadian Sex Buyers," (2010); Christine Milrod and Ronald Weitzer, "The Intimacy Prism: Emotion Management among the Clients of Escorts, "Men and Masculinities 15, no. 5 (2012): 447-67.

While there is growing evidence of the existence of female consumers in the sex trade (Ronald Weitzer, "Sociology of Sex Work," Annual Review of Sociology 35 (2009): 213-34), this issue has not infiltrated the larger debates, as these consumers represent a small fraction of the overall client population. As such, I focus on the male client, whose gender itself plays a significant role in the debates, particularly for the criminalization arguments that cast all prostitution in terms of "male violence against women," for example, Janine Benedet, "Paradigms of Prostitution," in Justice Bertha Wilson: One Woman's Difference, ed. Kim Brooks, (Vancouver: UBC Press, 2009), 131.; Diane Post, "Legalization of Prostitution is A Violation of Human Rights," Nat'l Law. Guild Rev. 68 (2011): 65; Max Waltman, "Prohibiting Sex Purchasing and Ending Trafficking: The Swedish Prostitution Law, Mich. J. Int'l L. 33 (2011): 133; Melissa Farley et al., "Attitudes and Social Characteristics of Men who Buy Sex in Scotland," Psychological Trauma: Theory, Research, Practice, and Policy 3.4 (2011): 369. 
Thomas Kemple and Laura Huey confronted this issue in the course of investigating surveillant practices of "skid row" neighborhoods. ${ }^{18}$ In a self-reflexive article, they analyzed the theoretical and ethical issues that arise when researchers find their fieldwork has rendered them unwitting subjects of surveillance. Citing Luhman's insights regarding the "paradox" inherent in empirical observation, ${ }^{19}$ they conclude that, "the irreducible blind spot of sociology may well be the systematic organization of its own observational gaze." ${ }^{20}$ To confront this blind spot, Kemple and Huey draw upon Pierre Bourdieu's call for social scientists to develop a "reflexivity reflex"; ${ }^{21}$ researchers of surveillance must theorize their own social interactions within their research, and acknowledge that they too participate in a "dialectic of visibility and invisibility."

In the introduction above, I described my attendance at a john school and narrated the thoughts I had that engaged this surveillance dialectic. There were many ways I could have conveyed this information, but I chose counterstorytelling, as formulated by certain branches of critical race and feminist legal theory. ${ }^{23}$ Counter-storytelling seeks to destabilize hegemonic sociolegal truths through an alternative account that, as Richard Delgado argues, "opens new windows into reality." ${ }^{24}$ Delgado further contends that counter-stories gain power not just by challenging the status quo analytically, but by employing a creative and affective methodology; "Their graphic quality can stir imagination in ways in which more conventional discourse cannot." ${ }^{25}$ Although counter-storytelling is most often used from a position of marginality, there is also epistemic value in counterstorytelling authored by someone occupying a relatively privileged or ambivalent position, as I did that day.

I classify this story as substantively "counter" for a number of reasons. As stated, it undermines the hegemonic story of the academic observer as objective, dispassionate, and invisible. ${ }^{26}$ It further attests to the ways that desire, curiosity, voyeurism, and exhibitionism weave through the research project, particularly where research on sex work is concerned. But the story also challenges the notion that "the gaze" is stable and fixed, attached to the one in power and applied to the one subordinated. For example, trying on different outfits on the morning of going to john school, I looked at myself through the filter of what I imagined to be the

18 Thomas Kemple and Laura Huey, "Observing the Observers: Researching Surveillance and Counter-Surveillance on 'Skid Row,'” in Surveillance \& Society 3, no. 2/3 (2002).

19 Ibid., 153: N. Luhmann, "Paradox of Observing Systems," in Theories of Distinction: Redescribing the Descriptions of Modernity, ed. William Rasch, trans. J. O’Neil (Stanford, CA: Stanford University Press, 2002), 79-93.

Ibid.

Ibid., 155 .

23 See, for example, Richard Delgado and Jean Stefanic, eds., Critical Race Theory: The Cutting Edge (Temple University Press, 2000) and Patricia J. Williams, The Alchemy of Race and Rights (Harvard University Press, 1991).

24 Richard Delgado, "Storytelling for Oppositionists and Others: A plea for Narrative," Michigan Law Review 87, no. 2411 (1989): 2414.

25 Ibid., 2415.

26 For an astute engagement with the affective impact of interviewing clients, see N. Hammond, "Tackling Taboo: Men who Pay for Sex and the Emotional Researcher," in New Sociologies of Sex Work, eds. Kate Hardy, Sarah Kingston, and Teela Sanders (Ashgate Publishing: 2010), 59-74. 
male gaze of a sex trade client. Then, during my encounter with one such client on the way into the classroom, I not only participated in a pleasurable exhibitionist display with my low- cut shirt but was also simultaneously a desiring subject. Each of our respective "gazes" intersected at the junction of sex, gender, class, race, ability, and differences in legal status. I read him as a criminalized, working-class, disabled, white male, while I identify as a noncriminalized, middle-class, nondisabled brown female. Normally, conversation can smooth out such sharp contrasts, but I was precluded from dialoguing, as I had only sought permission to watch and evaluate the program, not talk with clients. ${ }^{27}$ While I fully endorse the need for ethics approval of investigative activities, this epistemological method nonetheless manifested as power over. He was there to be disciplined, and I was there to study the disciplining, not to build bridges across clashing identities.

This dynamic was further accentuated by my mildly panoptic location in the back of the room from where I could watch the attendees watching the speakers. ${ }^{28}$ Even though the men would have spotted me as they walked in, once installed in their place, their front-facing seats prevented them from seeing me. And throughout the session, while I was taking notes on the speakers' lectures, my eyes would wander to the clients, and my multitasking brain would muse over the criminalized desires of these men. My wanton curiosity got the better of me not despite, but because of, my academic research on the taxonomy of "johns." But my externalizing academic gaze boomeranged back to my internalized male gaze when I found myself wondering where I might fit into this literal and figurative economy of desire. Finally, the man whom I had met on the way into the session also turned the gaze back on me during the break, when he questioned my agenda. In that moment, I was the one under scrutiny, uncomfortable and unsure what to say. His insistence that I talk to him-that I explain myself-was a subversion of the academic gaze.

There is one last reason that the story destabilizes dominant narratives. Rosie Campbell and Teela Sanders have argued, "the academic gaze on the street demonizes men who buy sex as aggressive, misogynistic deviants rather than ordinary, respectable members of the community." ${ }^{29}$ Mirha-Soleil Ross identifies further stereotypes of clients as, "Sexist hypocrites cheating on their wives. . . Horny brutes willing to buy women's bodies. . . Ugly boogey-men in trench coats

27 While empirical work on clients is not a part of my research mandate, the lack of direct client voices is a drawback to focussing exclusively on the construction of clients in regulatory discourse and processes.

28 The concept of the panopticon was developed by Michel Foucault in Discipline and Punish (Toronto: Random House Canada, 1977) based on Jeremy Bentham's vision of an ideal prison structure that would be panoptic - or all seeing. Bentham's architectural design placed authorities in a central tower from where prisoners could be observed at all times, but where they could not verify if and when they were being watched. The power of the panoptic gaze is its invisibility; the uncertainty would render self-disciplined and docile bodies. Foucault argued that while a literal translation of Bentham's prison did not manifest, the power dynamics of the panopticon have infiltrated modern practices of social control not just in penal institutions but throughout society. Surveillance literature has further developed the notion of the panopticon, specifically with regard to electronic monitoring systems. See D. Lyon, "Bentham's Panopticon: From Moral Architecture to Electronic Surveillance," Queen's Quarterly 98 (1991): 596-617.

29 Teela Sanders and Rosie Campbell, "Designing out Vulnerability, Building in Respect: Violence, Safety, and Sex Work Policy," The British Journal of Sociology 58, no. 1 (2007): 1-19 at 2. 
objectifying women." ${ }^{30}$ Client stigmatization rests on such characterizations. In contrast, my story positions them not just as objects of social control, but as objects worthy of desire. While second-wave feminism has argued that objectification is a dehumanizing process that renders women subordinate to male desires, ${ }^{31}$ objectification can also be empowering, pleasurable, and resistant, especially when the "objectified" is rejected by mainstream notions of attractiveness, as male clients have been. ${ }^{32}$ Moreover, as a female "objectifier," I challenge essentialist assumptions that women can only be passive subjects of harmful objectifying dynamics. In this sense, my argument supports David Bell's contention that surveillance can be sexy. ${ }^{33}$ As he states, "we are all of us, all of the time, modern voyeurs and modern exhibitionists," and one strategy of resistance to the surveillance society is to "flirt with surveillance." 34 To the extent that my presence disrupted the hegemonic stigmatization of clients, both in the moment with my dress, gaze, and words, and in recalling the incident in this paper, I hope to have harnessed some of this flirtatious power.

\section{John Sweeps}

Unfortunately, when it comes to state surveillance of clients, it turns out that flirtation can sometimes be a trap. To gather evidence to support the arrests of sex workers and clients, police officers engage in undercover "sting operations." This entails a police officer posing either as a sex worker or a potential client to encourage the suspect (whether a "john" or a "jane") to engage in solicitation. Although this might sound like entrapment, the Supreme Court of Canada allows police to employ such tactics, so long as the officers do not "induce" the criminal activity. ${ }^{35}$ Gary Marx has described such practices as "covert facilitation" that result in an "irony of social control."36 Undercover work in this area clearly involves sexualized interactions with suspects, verbally and sometimes even physically, in order to gather evidence to criminalize these very sexual dynamics. While Philip Walters has discussed the problematic nature of male officers engaging in sexual contact to gather evidence to incriminate a sex worker, ${ }^{37}$ I consider the dynamics of a female police officer passing as a sex worker to catch clients.

Bearing in mind that this is not legal entrapment, what stands out is the dialectic between surveillance and exhibitionism. The undercover female police officer performs as a sex worker, putting herself on display to entice the potential client.

30 Mirha-Soleil Ross, "Dear John” in Working Sex: Sex Workers Write about a Changing Industry, ed. Annie Oakley (Berkeley, CA: Oakley Seal Press, 2007), 211.

31 See, for example, C. MacKinnon, Feminism Unmodified, (Cambridge, MA: HarvardUniversity Press, 1987).

32 See Martha C. Nussbaum, “Objectification, "Philosophy and Public Affairs 24.4 (1995): 249-91 who argues for the possibility that objectification can have positive force in some circumstances. David Bell, "Surveillance is Sexy," 203-12.

Ibid., 211.

R. v Mack, [1988] 2 SCR 903.

G. T. Marx, "Ironies of Social Control: Authorities as Contributors to Deviance through Escalation, Nonenforcement and Covert Facilitation," Soc. Probs. 28, (1980): 221.

37 P. Walters, “"Would a Cop Do This?”: Ending the Practice of Sexual Sampling in Prostitution Stings," Law \& Ineq. 29, (2011): 451-77. 
As with a genuine sex worker, it is her job to exhibit herself and be sexy. In the distance, other police officers stake out the scene and wait for a suspect to approach. Meanwhile, cruising men-who have been deceived by the decoy-will look at her and assess her desirability. At the moment the client takes the bait, he consumes her through his male gaze, and she surveys him through her criminalizing gaze. Once the suspect communicates for "the purpose of prostitution," then an arrest can take place.

There are conspicuous parallel dynamics between the sex trade and its criminalizing enforcement. Granted, this may seem like an unremarkable point. A pseudo sex worker must attract a potential client, just as an authentic sex worker would have to; this is what undercover work is all about. But the undercover police officer is not just pretending to be a sex worker; she is using sexuality as part of her work. She is inciting the desire that she has been mandated to eradicate. Furthermore, this method of police work involves female police officers replicating the conventions of the femme fatale, a role often attributed to sex workers.

As film theorist Mary Ann Doane argues, the figure of the femme fatale personifies deception; "she never really is what she seems to be." 38 In fictional representations, she signifies a woman who offers a man the pretence of love and desire for ulterior motives. Accordingly, the femme fatale police investigator offers her sexualized exhibition, and thus inveigles men into providing self-incriminating evidence. At the climax of a classic film noir text, the femme fatale often makes a dramatic announcement where she reveals her scheming and shames her victim. Similarly, at the climax of the undercover sting, the jig is up once the would-be sex trade client communicates his criminal desire. The undercover officer signals to her colleagues, and the man undergoes the shaming ritual of arrest. And as with the fictive victim of the femme fatale, this can have a destructive impact on the duped man; his family life, financial welfare, immigration status, work prospects, mobility and/or reputation can all be compromised, if not completely destroyed, by his criminalization.

While the femme fatale figure in art is usually punished for her deception, ${ }^{39}$ recent studies indicate that the "femme fatale" police officer may benefit from these sting operations. ${ }^{40}$ For example, research based on qualitative interview data of 25 female officers found that many regarded the work as exciting, a welcome break from routine police work, and an opportunity to advance their careers. ${ }^{41}$ One interviewee stated: "It's a blast, I love it, and I have a great time . . . I get to forget that I'm a cop. . . . You get to play with people and I get to be a little bit foul mouthed. I have a great time playing 'ho." 42 This positive experience of undercover sting operations demonstrates a "power that lets itself be invaded by the

Mary Ann Doane, Femmes fatales (Routledge, 1991), 1.

Ibid., 2

40 Lynda M. Baker, "Undercover as Sex Workers: The Attitudes and Experiences of Female Vice Officers, "Women and Criminal Justice 16, no. 4 (2005): 25-41; M. Dodge, D. Starr-Gimeno, and T. Williams, "Puttin' on the Sting: Women Police Officers' Perspectives on Reverse Prostitution Assignments," International Journal of Police Science and Management 7(2), (2005): 71-85.

41 Ibid., 77-8.

42 Ibid., 78. 
pleasure it is pursuing." 43 This interviewee-who clearly possesses an uncanny self-awareness-enjoys letting go of the constraints of her cop identity and adopting a "ho" persona. In addition, the pleasure she takes in her fake deviant identity indicates what I have previously referred to as "outlaw envy". ${ }^{44}$ employ this concept to capture the ways that non-sex workers can appropriate outlaw sex worker activities not just for strategic use-in this case to incriminate clients-but also for titillation. Implicit in outlaw envy is the notion that sex workers enjoy a transgressive and libidinal freedom denied to sexually normative subjects. Of course, the police officer's privileged appropriation does not attract the risks that a genuine sex worker faces. This quotation thus demonstrates that the surveillance of clients and the controlled simulacrum of sexual "deviance" can involve exhibitionist pleasure in conjunction with regulatory power.

\section{3. "Dear John" Letters and the Panoptic Police Gaze}

Police surveillance efforts not only lead to arrests, but may also have other disciplinary consequences. In Ottawa, when police identify a man communicating with a sex worker, in the company of a sex worker or cruising in an area identified as a 'prostitution stroll', he may be questioned. If there is insufficient evidence to justify an arrest, the officer may send the suspect a 'community safety letter', more colloquially referred to as a "Dear John" letter, through registered mail. While the police maintain its purpose is only to educate, there are clear punitive effects that follow. For example, as civil liberties associations argue, the practice infringes privacy, effectively disciplining a man who has not been charged, let alone convicted, of a crime. ${ }^{45}$

A sample letter provided by the Ottawa police department reveals a rhetorical strategy of using mixed messages to inculpate the man, while also constructing him as a team player. The beginning of the letter sets the tone by communicating to the suspected client that a record has been kept of his encounter with the police:

Dear $[\mathrm{X}]$,

\section{RE: $[X]$ NEIGHBOURHOOD CONCERN}

\section{Your Vehicle:}

\section{Location Stopped:}

\section{Date \& Time Stopped:}

The police thus flex their panoptic power by this follow-up postal tactic, intruding into the suspect's residence and piercing the public/private divide.

However, the rest of the letter makes no mention of the suspect's allegedly wrongful actions. Instead it provides "information" about the harms of prostitution as a vehicle for drug use and sexually transmitted infections. It further identifies

\footnotetext{
43 Michel Foucault, The History of Sexuality, 1st ed. (New York: Vintage Books, 1990), 45.

44 Ummni Khan, "Running In(To) The Family: 8 Short Stories about Sex Workers, Clients, Husbands, and Wives," Journal of Gender Social Policy \& the Law (2011): 495-526.

45 Andrew Seymour, "Cleaning up the Capital," The Ottawa Citizen, October 2, 2007, accessed July 22, 2014, http://www.canada.com/story_print.html?id=293236af-90ac-41ff-a083-da44aa 19b504\&sponsor=.
} 
harms caused to the community, referring to increased traffic and-drawing on the sacred status of the reproductive family-stating that children are finding used needles and condoms in playgrounds and public areas.

Rather than directly blaming the recipient for these problems, the rest of the letter addresses him as an ally. Each of the five paragraphs that make up the letter ends by including the suspected john as part of the solution. Paragraph one explains the purported purpose of the letter: "This Community Safety Letter is our way of informing you of the important initiative underway within this neighbourhood and to seek your support." Paragraph two entreats: "We need your help to improve this community." Paragraph three gives explicit instructions: "You can do your part by refraining from bringing your vehicle into this area unnecessarily." Paragraph four marks the goodwill that exists between the letter writer and recipient: "We welcome your support for this important community safety initiative." And the last paragraph ends with anticipation of compliance: "Your cooperation in this matter is appreciated."

The letter's social control strategy thus eschews direct accusation. Instead, by sharing select information gathered by the police surveillance, the letter aims to produce a docile body, inculcating the panoptic fear that the next time the suspect cruises for sex work, he will likely find himself again under the police gaze. The tone of the rest of the letter, which greets the suspect as a partner in "community safety," works in conjunction with the panoptic threat. The letter couches a reprimand within the folds of an information bulletin. While this pretense can be viewed as a tactful way of warning the recipient, it is also a technique of subjection. The letter does not contemplate that the recipient may contest the antiprostitution views of the police force. By presupposing the agreement, cooperation, and support of the letter recipient, he is coercively hailed as a law-abiding citizen who shares the moral values of the police force. ${ }^{46}$ Any alternative view of the significance and reality of street prostitution is rendered unintelligible.

Edmonton also sends "Dear John" letters, but unlike Ottawa's police department, the Edmonton police do not ensure that the letter is delivered directly to the suspected client. In Edmonton the letter is sent to the registered owner of the vehicle, not, as in Ottawa, to the suspect driving the car. In a media interview from 2007, Sergeant Spinks had no concerns about the privacy issues, stating, "If you want to take the risk of driving your wife's car down there, then your wife will get the letter.... She should know if you are having sex with a prostitute down in those areas. The health information outweighs the not knowing." ${ }^{37}$ In terms of due process rights, this is clearly troubling. In the sergeant's perspective, police suspicion that someone intended to engage a sex worker-which could include noncriminal behavior that might just as easily be explained as a person looking for an

46 My use of the word "hail" draws upon Althusser's conceptualization of the way ideological utterances produce subjects through a coercive "hail" or "interpellation" that is based on a presumed "obviousness" of the state of reality, in this case, the "obviousness" that the letter recipient would agree with the police's description of the social problems produced by prostitution; see Louis Althusser, "Ideology and Ideological State Apparatuses," in Lenin and Philosophy and Other Essays (London: New Left Books, 1971), 172].

47 Andrew Seymour, "Cleaning up the Capital." 
address-is sufficient to conclude that the person is "having sex with a prostitute." However, the fact that the "Dear John" letter is not a penalty imposed directly by the Criminal Code means that officially the suspect is not being punished, but rather educated.

Yet, of course, the letter is an informal punishment intended to deter future behaviour. The suspected sex trade client not only receives a written reprimand but is potentially exposed to his family or employer. This epistolary exhibitionism gathered by police surveillance relies, in part, on the threat of workplace troubles or family breakdown to produce both specific deterrence (the individual will refrain from "john" activity in the future) and general deterrence (through the media, the police inform the public about the existence of this program). Thus, surveillance techniques, even if they do not lead to an arrest, can subjugate the individual under scrutiny by calling upon his community to be privy to the gathered data and to share in the task of surveilling its citizens and administering discipline.

\section{Report-A-John forms and the Synoptic Public Gaze}

In identifying clients, police in Edmonton and Laval rely not only on police investigation but also on tips from the public. While members of the public can always report suspicious behaviour to their local police, Edmonton and Laval have initiated dedicated reporting systems that target clients. In this way, the reification of a "john" is tied up with his construction as a pressing social problem that requires immediate "john"-specific measures, as illustrated by this public sign.

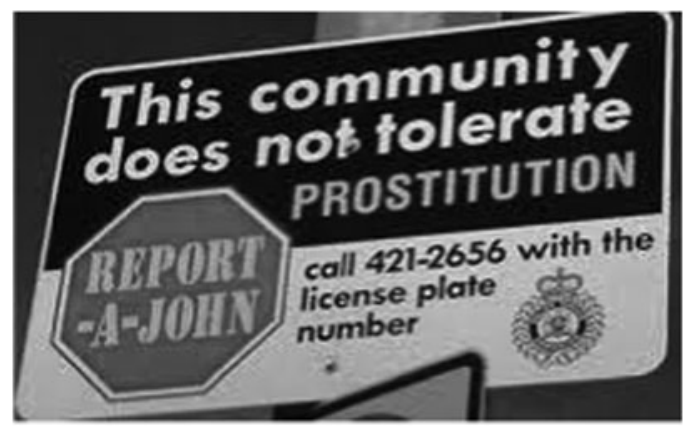

In Alberta, this strategy began in 2006, when the Edmonton Police introduced a "Report-A-John" program as part of their strategy to combat prostitution. ${ }^{48}$ On their "Report-A-John" web page, the police request surveillance information from the public in "the tracking of 'john' activity." If a member of the public notices a potential client, an online form can be filled out. The form asks for standard identification information, such as license plate and vehicle description, as well as for

48 “Report A John,” Edmonton Police Service, accessed July 22, 2014, https://www.edmontonpolice. $\mathrm{ca} /$ communitypolicing/familyprotection/prostitution/reportajohnform.aspx. 
the location, date, and time of the "john" sighting. The suspicious activity must also be specified if possible. The website offers a list of options:

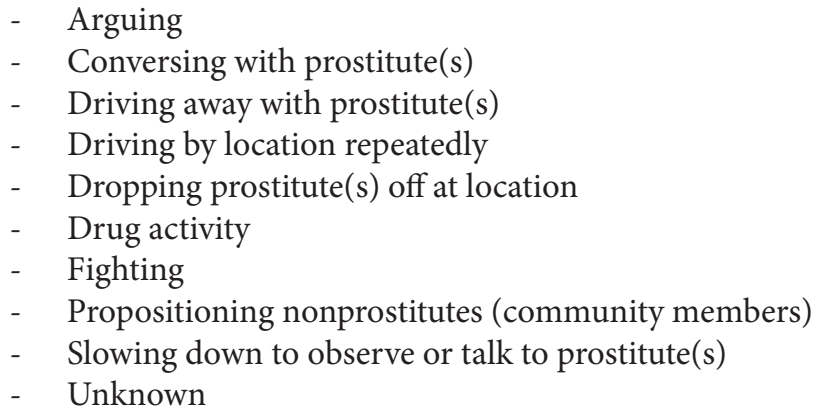

According to an interview my research assistant had with the Edmonton police in 2011, this form does not lead to any direct consequences on its own. The reports are used only for intelligence purposes. Yet, by publicly promoting their Report-AJohn initiatives, the police put potential clients on notice that they are being scrutinized not just by the police, but by ordinary citizens. Again, the maligned behaviour can include noncriminalized activity, such as being friends with a sex worker or being lost. In this way, the form perpetuates "structural stigma," renders sex workers as a contaminating force; anyone seen even associating with a sex worker (or someone perceived as a sex worker) is tainted as a dubious character the police should be made aware of.

In 2011, Laval Police initiated a similar reporting program, dubbed "Projet Cyclope." ${ }^{50}$ As in Edmonton, residents who observe persons they identify as clients can fill in a template report generated specifically to target these men. ${ }^{51}$ Unlike Edmonton's form, the report does not offer preset options that classify client behaviour, but rather asks for a general description of the suspicious activities: "Décrire avec précision les agissements du conducteur qui vous permettent de conclure qu'il s'est livré à de la solicitation à des fins de prostitution." ${ }^{\text {"Th }}$ The informant must also provide his or her own name in order to protect people from false accusations. This is particularly important because, according to Lavalnews.ca,

49 Chris Bruckert and Stacey Hannem, "Structural Stigma, Social Profiling, and the Abuse of Police Power in Ottawa," in Selling Sex: Experience, Advocacy, and Research on Sex Work in Canada (Vancouver: UBC Press, 2013), 297. See also Gail Pheterson, “The Whore Stigma: Female Dishonor and Male Unworthiness," Social Text 37 (1993): 39-64.

50 I find it somewhat ironic that the chosen name for this program alludes to the mythological one-eyed creatures, known not only for their immense power, but also for their savagery. See Andrew Delahunty and Sheila Dignen, "Cyclops," in The Oxford Dictionary of Reference and Allusion (New York: Oxford University Press, 2010), accessed June 3, 2013, http://www.oxfordreference.com. proxy.library.carleton.ca/view/10.1093/acref/9780199567454.001.0001/acref-9780199567454e-508

51 "No to Solicitation and Sexual Harassment," Ville de Laval - government website, accessed July 22, 2014, http://www.info.ville.laval.qc.ca/wlav3/index.php?pid=1020.

52 Author's translation: Describe in detail the driver's activities that led you to conclude that he was engaging in solicitation for the purposes of prostitution. Ville de Laval - government website; Rapport D’observation: Projet Cyclope. 
unlike Edmonton, Laval police will send a "Dear John" letter based on these reports alone: "The so-called 'johns' who get reported are sent a letter by the police, informing them that they are the subject of a complaint involving solicitation of prostitution." 53 The information used to justify the dispatch of a "Dear John" letter is not a product of police surveillance, but of public observation.

This disciplinary strategy that calls upon the community to report on suspicious activity shifts the dynamic from the "panoptic" police gaze to the "synoptic" community gaze, where the many watch the few. ${ }^{54}$ While the neologism "synopticism" is rooted in Mathiesen's notion of a "viewer society", in which a large number of people watch a few famous individuals through the mass media, the more discrete "Report-A-John" initiatives are also arguably drawn from a synoptic impulse. As with all neighbourhood watch strategies, the "Report-A-John" philosophy relies on the public to police themselves. ${ }^{55}$ The synoptic effect then works in tandem with the more formalized panoptical effect, reinforcing their overlapping disciplinary functions. ${ }^{56}$ Through the "Dear John" letter, the police inform the suspect that his criminal activities are being watched and recorded, even if the police themselves are not present. The potential client thus learns that not only does he have to worry about formal police stakeouts, but also about neighborhood snoops informing the police.

\section{Media Releases}

A number of police forces in Canada, the United States, and England release the names of men arrested for soliciting sex work to newspapers and directly to the public on their websites. Teela Sanders argues that this "naming and shaming" deterrent strategy establishes the media as an extension of the criminal justice system. ${ }^{57}$ Courtney Persons further identifies this practice as a "shame punishment" that "directly, pointedly, and consistently aim [s] at communication to wider society." ${ }^{28}$ This communicative channel flows in two ways. First, members of the public are called upon to alert the police if they observe prostitution. Second, when the men are apprehended through sting operations, the police alert the public to the arrests.

The titles of such media statements are often indicative of prevailing attitudes toward those who sell or buy sexual services. News articles and media releases frequently refer to sex work sting operations as prostitution or

53 Martin C. Barry, "Laval Police Hope to Curb Prostitution with Project Cyclope," The Laval News, July 4, 2011, accessed July 22, 2014, http://lavalnews.ca/article/Laval-Police-hope-to-curbprostitution-with-Projet-Cyclope-191307.

54 Thomas Mathiesen, “The Viewer Society: Michel Foucault's 'Panopticon' Revisited, ”Theoretical Criminology 1, no. 2 (1997): 215-34.

55 Dennis P. Rosenbaum, "Community Crime Prevention: A Review and Synthesis of the Literature, "Justice Quarterly 5, no. 3 (1988): 323-95.

56 S. P. Hier, "Probing the Surveillant Assemblage: On the Dialectics of Surveillance Practices as Processes of Social Control," Surveillance \& Society 1 (3) (2003): 399-411.

57 Teela Sanders, Paying for Pleasure: Men Who Buy Sex (Devon, UK: Willan Publishing, 2008), 152.

58 C. G. Persons, "Sex In The Sunlight: The Effectiveness, Efficiency, Constitutionality, and Advisability of Publishing Names and Pictures of Prostitutes' Patrons," 49 Vand. L. Rev. (1996): $1525-35$. 
john "sweeps." 59 As John Lowman argues, the media perpetuates a "discourse of disposal" with regard to sex workers and their clients. ${ }^{60}$ The term "sweep" objectifies participants in the sex trade as garbage that needs to be removed to "clean up" the streets. Moreover, as sex workers have been recently recast as "victims" in the social imaginary, the police "sweeps" have shifted pointedly toward the "johns" as contaminants. In Ottawa, for example, since 2013, all sting operations have focused on clients. ${ }^{61}$ Such sweeps are then reported through media releases.

An examination of the rhetoric of police media releases and news articles demonstrates the reciprocal relationships between police and public surveillance and between surveillance, disclosure, voyeurism and exhibitionism. For example, media releases from Peel Regional Police specify whether arrests were initiated because of residents' complaints. ${ }^{62}$ The police thus establish a surveillant feedback loop by constructing themselves as responsive to community concerns and by putting potential clients on notice of the synoptic gaze of the public. Such statements further reveal the undercover strategy of the police, as they often communicate that "plainclothes officers" conducted the investigation. The disciplinary function of the undercover surveillance works in conjunction with the media disclosure of this strategy for purposes of general deterrence. This strategy counts on potential clients reading the release and deciding that the risk of being caught and the public shame that would ensue from a subsequent media release outweigh the pleasure of a paid sexual encounter. Such media releases end by highlighting the police force's ability to get results by charging a number of men with prostitution-related offences. A causal link from the public complaints to the police arrests is established. Again, this not only establishes the partnership between the police's panoptic strategies and the community's synoptic impulses, but it also puts the potential sex trade client on notice: You are being watched. Not just by Big Brother, but also by your community "brothers" and "sisters."

Some police reports also identify each arrested man by name, age, and city of residence. ${ }^{63}$ As the men are not minors, there is nothing legally improper about

59 See for example: 680 News staff, “Recent 'John Sweep' Results in Ten Arrests," 680 News, December 9, 2009, accessed June 25, 2014, http://www.680news.com/2009/12/09/recent-john-sweep-resultsin-ten-arrests/; "Editorial: John Sweep was Right Thing to Do," The Belleville Intelligencer, September 17, 2013, accessed June 25, 2014, http://www.intelligencer.ca/2013/09/17/editorialjohn-sweep-was-right-thing-to-do; Sherri Zickefoose "After Citywide Prostitution Sweep, Calgary Police Admit it's only a Small Dent in Sex Trade," Global News Toronto, April 23, 2011, accessed June 25, 2014, http://globalnews.ca/news/8748/after-citywide-prostitution-sweepcalgary-police-admit-its-only-a-small-dent-in-sex-trade/; Megan Gillis, "Ottawa Cops to Start up 'John Sweeps' during Busy Spring," Ottawa Sun, March 5, 2014, accessed June 25, 2014, http:// www.ottawasun.com/2014/03/05/ottawa-cops-to-start-up-john-sweeps-during-busy-spring.

60 John Lowman, "Violence and the Outlaw Status of (Street) Prostitution in Canada," Violence Against Women 6, no. 9 (September 2000): 987.

61 "Ottawa Police Shift Focus to Johns in Sex-trade Sweeps," CBC News, January 7, 2014, accessed July 22, 2014, http://www.cbc.ca/news/canada/ottawa/ottawa-police-shift-focus-to-johns-in-sextrade-sweeps-1.2486263.

62 See, for example: http://www.peelpolice.ca/News/Media\%20Archive.aspx?Page=60\&MainCont ent $=2512$.

63 “16 September 2013 - Directed Enforcement - Downtown," Belleville Police Service, accessed July 22, 2014, http://www.police.belleville.on.ca/mediareleasess25.php?command=viewArticle\&ID= 1679\&currentFeed=1\&t=16-September-2013---Directed-Enforcement-\%96-Downtown. The names in this police report were reproduced in this media article: W. Brice McVicar, "Johns Busted Downtown," September 16, 2013, accessed July 22, 2014, http://www.intelligencer.ca/ 2013/09/16/johns-busted-downtown. 
this disclosure; this information is a matter of public record. Yet, this is clearly a disciplinary tactic. The deliberate exposure of their identities is at the crux of the shaming ritual used against men who have not been convicted of any crime. For the men who have been named, the publication of their arrest to family, friends, acquaintances, colleagues, and employers may have a devastating impact on their lives, whether the charge is ultimately proven or not. ${ }^{64}$ And for the reader, voyeuristic pleasure is harnessed. She can learn about the naughty sexual behaviour of a member of her community, and whether she is acquainted with him or not, having access to the name and age of the arrested man can evoke a personalized image of illicit activity.

Many police agencies, as well as online news sources, keep an archive of media statements on the Internet. As a result, in addition to being published in physical newspapers, the electronic data remains accessible, and the exposure remains public, suspended in time. Thus, surveillance is not temporally bound. Its disciplinary aftershocks can continue to provide voyeuristic access to the gathered information.

\section{John School}

The final social control strategy that this chapter addresses brings us full circle to my introductory anecdote: john school. Alleged clients who are caught by the exhibitionist tactics of undercover sting operations might find upon arrest that they are given two options: trial or school. ${ }^{65}$ In cities like Ottawa, Vancouver, Edmonton, and Toronto, john schools operate as preconviction diversion programs in the criminal justice system. Generally, men who have been arrested for the first time and "accept responsibility" for their criminal behaviour can pay a fee of approximately $\$ 500$ to attend a one-day workshop instead of undergoing a trial. Successful participation in this program allows the arrested men to avoid the risk of conviction and a criminal record.

The program seeks to alter the attitudes and behaviour of the men by "educating" them about the harms of prostitution. Typically, a number of speakers are brought to the workshop to share professional or experiential knowledge. ${ }^{66}$ On the professional side, a crown attorney explains the laws applicable to prostitution and the conditions of john school. In order to challenge the notion that sex workers willingly participate in the trade, a police officer or social worker attests the women are being controlled by drug addiction, pimps, or most likely both. Relying on scientific discourse, a sexual health nurse provides information about the transmission of sexual infections. In terms of experiential knowledge, an "ex-prostitute" chronicles her life story, reinforcing much of the professional construction of

64 C. G. Persons, "Sex in the Sunlight: The Effectiveness, Efficiency, Constitutionality, and Advisability of Publishing Names and Pictures of Prostitutes' Patrons," 49 Vand. L. Rev. (1996): 1565-69 at 1525 .

65 J. Lowman, "Prostitution Law Reform in Canada," in Toward Comparative Law in the 21st Century (Tokyo: Chuo University Press, 1998), 919-46.

66 My knowledge of the typical john school agenda is based on interviews conducted with the organizers of these programs in Edmonton, Hamilton, Ottawa, Toronto, Saskatoon, Sudbury, Vancouver, Windsor, Winnipeg, and Peel region. I also observed two john school sessions. 
prostitution, but with personal details relating to issues like family breakdown, poverty, drug addiction, violent incidents, or sexually transmitted infections. In what is often the most castigating presentation, a neighborhood representative from an area experiencing sex trade activity recounts how prostitution ravaged her community and subjected women who were not sex workers to unwanted solicitation from clients. Finally, a speaker who self-identifies as a recovering sex addict shares his struggle with this disease and its connections to the sex trade.

Fisher and colleagues have analyzed the sociolegal dynamics of the Toronto john school and raised important social justice concerns. ${ }^{67}$ While recognizing some potential benefits of the program, the authors identify potential violations of due process rights and the disproportionate number of racialized and working class men who wind up in attendance. Van Brunschot shares these concerns in her analysis of Canadian john schools and discourses of community policing. ${ }^{68}$ Problematizing the rationale and implementation of john schools, she concludes: "The narrow view of community, the rhetoric of rehabilitation and 'informality' coupled with appeals to rationality and the threat of 'formal' punishment, as well as the expansion of policing methods and the resulting widening net of social control, undermine any good that prostitution offender programs might be argued to represent." ${ }^{\text {69 }}$ Fisher and colleagues and Van Brunschot suggest that despite the purported intent to educate, the men are not given access to the various and conflicting research on sex work; instead, they are presented with a seamless and simplistic vision of harm to the sex worker, the clients, their families, and the community. In addition, both the required fee and the shaming tone indicate that the program remains within a punitive realm, despite claims of its educative agenda. Drawing on insights from both these articles and my own observation of three john schools, I want to consider how the dialectic of surveillance and exhibition affects the dynamics of the program.

As stated earlier, john schools" "students" are made up of alleged clients who have been caught through sting operations. The surveillance techniques used in these undercover operations deviantize these men to justify their mandatory "education," thus reinforcing the power-knowledge dyad. During the program itself, the "deviants" are, of course, the ones who are doing the "looking" - but this is not surveillant looking, this is coerced reception. The men are effectively a captive audience. While the Crown attorney and the program facilitators maintain that the men are participating voluntarily, as Fisher and colleagues and Van Brunschot point out, classist and racist power structures can influence who ends up being caught by these sting operations, and for those who are caught, who opts for diversion over the traditional criminal justice system. In addition, the men are informed that they can be evicted if they disrupt the programming, including if they fall

\footnotetext{
67 B. Fischer, S. Wortley, C. Webster, and M. Kirst, "The Socio-legal Dynamics and Implications of 'Diversion': The Case Study of the Toronto John School Diversion Programme for Prostitution Offenders," Criminology and Criminal Justice 2 (4) (2002): 385.

68 E. G. Van Brunschot, "Community Policing and 'John Schools," Canadian Review of Sociology/ Revue Canadienne De Sociologie 40 (2), (2003): 215-32. 
asleep or refuse to take off their hat. ${ }^{70}$ This induction of the docile body exemplifies Foucault's observation in his chapter on "the Panopticon" that jails and schools share an uncanny resemblance. ${ }^{71}$ John school is a carceral space, not because the men are barred from leaving, but because the threat of jail and a criminal record hang over them-like the sword of Damocles-throughout their participation.

The threat then pins the men to their seats and, for the most part, keeps them quiet. Consequently, the facilitators and their invited speakers have an uninhibited space to perform their truth claims. In this way, john schools operate as a form of institutional exhibitionism, where facilitators engage in sexual discourse and generate sanctimonious pleasure in producing knowledge to a group of men who remain acquiescent under legal constraint. And while the ostensible goal of the program is the sexual repression of clients through education, as Foucault explains in The History of Sexuality, the effect of such mechanisms is a proliferation of sexual speech that generates both power and pleasure. ${ }^{72}$

Each speaker engaged in sexual discourse in a different fashion, from the Crown Attorney's technical discussion of prostitution-related law to the community representative's histrionics about being treated "like a prostitute". From my observation of three john school sessions, the most sexually charged presentation was the one presented by the recovered sex addict. In this regard, allow me to elaborate on how the sex addiction component engages with issues of self-surveillance and exhibitionism.

The recovering sex addict speakers went into explicit detail about the quantity and quality of their previous "depraved" activities. After regaling us with these sexual exploits, the presenters warn, however, that for sex addicts, satiation or happiness is never achieved. The only hope for a truly satisfying life for such men is to seek a therapeutic intervention with a community of recovering addicts. Interestingly, accepting this pathologization exacts a self-disciplinary toll. The unenlightened addict must scrutinize his desires and continue the work after "sobriety" (aka sexual moderation) is achieved. As Keane argues in her deconstruction of addiction discourses, "the recovering addict identity is a precarious and uncomfortable state marked by constant self-surveillance and the ever present threat of relapse." ${ }^{\text {73 }}$ Indeed, one sex addiction presenter stated it was a constant battle to resist slipping back into his "old self." By way of example, he pointed to some condoms that the sexual health nurse had provided. He explained that just the sight of condoms in such abundance disturbs/excites him, as in his own life, he endeavours to keep signs of "lusting" off his radar.

This imperative to avoid "lusting" exemplifies how the sex addiction model fits into a neoliberal responsibilization framework, according to which it is up to the

70 Falling asleep can be a real issue, not because it conveys disrespect, but because it can reflect the class position of the man. For example, during one john school I observed that took place from 8:30 a.m.to 4:00 p.m., one man had come off of an all night work shift as a taxi driver and was clearly exhausted and struggling to stay awake during the speakers' presentations, which were largely lectures and not interactive.

71 Michel Foucault, Discipline and Punish: The Birth of the Prison (New York: Vintage, 1995), 228.

72 Michel Foucault, The History of Sexuality, 17-35.

73 H. Keane, What's Wrong with Addiction? (New York: New York University Press, 2002), 162. 
individual addict to seek help and avoid temptation. In this vein, sex addiction theory depoliticizes the issue of prostitution and recasts it within an objective health discourse. At the same time, the reification of certain sexual behaviour as an addiction proliferates sexual discourse, cultivating new sexual taxonomies along with opportunities for the exhibitionist satisfaction of confession. The workshop participants have thus been invited to partake in this technology of the self, ${ }^{74}$ where the gratification of paid sex is exchanged for the pleasures of solipsism, self-surveillance, and the threat-and excitement-of sexual temptation hiding around every corner.

\section{Conclusion}

Since male desire to purchase sex has traditionally been accounted for through gendered theories of natural masculine libido, clients have historically been overlooked by criminal law and social science investigation. This ideology has recently shifted. The emergence of clients as objects of academic inquiry in the last thirty years has been accompanied by an increase in client-specific policing and stigmatizing discourse. This essay evidences this increase by analyzing five social control strategies of clients, along with my own research process in this area. No longer anonymous, tolerated or biologically justified, the male client is now constructed as a "john," a deviant sexual identity and a menace to the community, deserving criminalization, exposure, and shame. ${ }^{75}$

These social control measures engage a complex surveillance dynamic. I have drawn on a number of concepts, most relevantly Foucauldian (panoptic, synoptic, self-disciplining, power/pleasure nexus) and psychoanalytic-cinematic (voyeurism, exhibitionism, the gaze) to flesh out this dynamic. As my analysis demonstrates, these contrasting modalities of power and engagement often interlace. For example, the police panoptic power to monitor clients without being detected in sting operations is based, in part, on exhibiting themselves under disguise as sex workers. The rhetoric of "john sweeps" presents clients as social waste and encourages a voyeuristic economy, where their deviancy becomes a spectacle for public consumption. Upon arrest, police utilize the media's power of exposure to exhibit the names of clients as a shaming and deterring measure. The synoptic gaze of community members who submit Report-A-John forms works to instill self-discipline in potential clients, allowing police to exhibit this information through public announcements or follow-up "Dear John" letters. When accused clients are sent to john school as an education-punishment, they become a captive audience for antiprostitution exhibitionism. Thus, while a number of scholars have detected voyeuristic elements in surveillance tactics, particularly in the surveillance of sexuality, I have argued that in the case of clients at least, exhibitionist elements are also crucial to the process of social control.

74 Michel Foucault, Technologies of the Self: A Seminar with Michel Foucault (Amherst: University of Massachusetts Press, 1988).

75 For a sensationalist rendition of this ideological stance, see Victor Malarek, The Johns: Sex for Sale and the Men who Buy it (New York: Skyhorse Publishing, 2011). On the other hand, some clients self-identify as "johns," see Chester Brown, Paying for It: A Comic-strip about Being a John (Montréal, Quebec: Drawn \& Quarterly, 2011). 
I have also self-interrogated in this essay. Through critical storytelling, I offered my own experiences of researching john schools that demonstrated a complex dynamic of academic surveillance, including elements of voyeurism, exhibitionism, and crisscrossing gazes. While my intentions are different from those motivating the state- and community-directed surveillant measures I then analyzed, it is important to consider how one's research can become implicated in the very network of social control that one seeks to challenge. In this current moment, there is a proliferation of social scientific studies on "why men buy sex"; some of these seek to humanize this demographic, and others seek to demonize it. ${ }^{76}$ While my work - to the extent that it engages with the ontology of clients-adheres to the humanizing agenda and challenges their criminalization, I might also be caught up in the desire to look at clients, reflected in the anticlient dynamics of police and antiprostitution feminist practices. Borrowing from Foucault: "the pleasure that comes of exercising a power that questions, monitors, watches, spies, searches out, palpates [and] brings to light," client condemners. While I offer only preliminary thoughts on the connections and contrasts between academic and criminalizing surveillance, I hope that by practicing Bourdieu's reflexivity reflex, I may encourage other sexuality scholars to explore this question by turning the academic gaze back on themselves. ${ }^{78}$ This is particularly important for non-sex worker researchers analyzing sex work, as our affective investments often remain invisible, but can impact our analytical frame. My hope is that by exposing both the perverse subtext of the police and community surveillance of clients, as well as my hidden thoughts as I studied john school, I have demonstrated that surveillance is not a straightforward strategy of social control. Instead, surveillance is a site of ambivalence that includes resistance and pleasure alongside, and sometimes in conjunction with, coercion and discipline.

\author{
Ummni Khan \\ Carleton University \\ Law and Legal Studies \\ C473 Loeb Building \\ 1125 Colonel By Drive \\ Ottawa, ON, K1S 5B6 \\ ummni_khan@carleton.ca
}

\footnotetext{
76 In the humanizing vein, see Chris Atchison, "Report on the Preliminary Findings for John's Voice: A Study of Adult Canadian Sex Buyers" and Teela Sanders, Paying for Pleasure: Men who Buy Sex. In the demonizing vein, see Melissa Farley et al., "Comparing Sex Buyers with Men Who Don't Buy Sex: 'You Can Have a Good Time with the Servitude' vs. 'You're Supporting a System of Degradation," Prostitution Research \& Education (2011), http://www.prostitutionresearch.com/ pdfs/Farleyetal2011ComparingSexBuyers.pdf.

77 Michel Foucault, The History of Sexuality.

78 This political strategy of self-questioning is derived from Brenda Cossman's, "Turning the Gaze Back on Itself: Comparative Law, Feminist Legal Studies, and the Postcolonial Project," Utah L. Rev. (1997): 525.
} 